\title{
PISANGAN NUANSA RETRO
}

\author{
Hendi Setiawan ${ }^{1)}$, Sidhi Wiguna Teh ${ }^{21}$ \\ 1)Program Studi S1 Arsitektur, Fakultas Teknik, Universitas Tarumanagara, hendi.setiawan97@gmail.com \\ 2)Program Studi S1 Arsitektur, Fakultas Teknik, Universitas Tarumanagara, sidhi@ft.untar.ac.id
}

Masuk: 14-07-2020, revisi: 31-07-2020, diterima untuk diterbitkan: 24-09-2020

\begin{abstract}
Abstrak
Masyarakat kota merupakan masyarakat modern yang memiliki keseharian dengan mobilitas serta berbagai rutinitas dan aktivitas yang tinggi. Keseharian ini kemudian menuntun masyarakat kota dengan gaya hidup serba praktis. Tuntutan gaya hidup masyarakat kota sering sekali menuntut untuk menghadapi suatu pekerjaan dan kegiatan yang begitu menyita waktu sehingga sering sekali membuat masyarakat lupa akan kebutuhan lainnya termasuk istirahat. Penelitian ini memiliki tujuan untuk menjawab kebutuhan masyarakat, terutama masyarakat Pisangan Timur yang merupakan salah satu daerah di kecamatan Pulo Gadung yang di dominasi oleh perumahan, peruntukan lahan yang dipergunakan untuk pemukiman/perumahan yaitu sebesar $89.63 \%$ dan sisanya dipergunakan untuk jalan, jalur hijau/taman, dan danau, masalah ini kemudian diperburuk dengan adanya penggusuran pasar loak yang merupakan pusat berkumpulnya masyarakat, kemudian dengan minimnya jumlah lahan yang kemudian di peruntukan untuk ruang terbuka dan ruang untuk berkumpul, melalui peran arsitektur diharapakan dapat menciptakan ruang komersial berupa pasar loak yang menjadi tempat beristirahat dan berkomunikasi antar penghuni sehingga masyarakat dapat memiliki ruang untuk saling berinteraksi dengan nyaman. Dalam penelitian ini metode yang digunakan adalah pertama, melakukan studi dan observasi; kedua, mempelajari dan meninjau kebutuhan dari masyarakat sekitar serta kebutuhan untuk melepas kejenuhan dan beristirhat ditengah aktivitas yang padat; ketiga, menyusun program sesuai dengan hasil survei, observasi serta menjawab kebutuhan masyarakat sehingga tujuan proyek akan tercapai.
\end{abstract}

\section{Kata kunci: Arsitektur; Istirahat; Kebutuhan; Masyarakat}

\begin{abstract}
Urban society is a modern society that has daily mobility and high routines and activities. This daily life then guides the city community with an all-practical lifestyle. The lifestyle demands of the urban community often demand to face a job and activity that takes up so much time that it often makes people forget about other needs including rest. This study aims to address the needs of the community, especially the East Pisangan community which is one of the areas in Pulo Gadung sub- district dominated by housing, land allotment used for housing / housing that is equal to $89.63 \%$ and the rest is used for roads, green lanes / parks, and lakes, this problem is then exacerbated by the eviction of the flea market which is the center of community gathering, then with a minimal amount of land which is then earmarked for open space and space to gather, through the role of architecture it is hoped that it can create a commercial space in the form of a flea market which is a place rest and communicate between residents so that people can have space to interact comfortably with each other. In this research the methods used are: first, conducting studies and observations; secondly, studying and reviewing the needs of the surrounding community and the need to relieve boredom and rest in the midst of a dense activity; third, compile the program in accordance with the results of the survey, observation and answer the community's needs so that the project objectives will be achieved.
\end{abstract}

Keywords: Architecture; Needs; Rest; Society 


\section{PENDAHULUAN}

\section{Latar Belakang}

Absennya ruang publik kemudian membuat tidak adanya kehidupan publik yang informal, hal ini kemudian berpengaruh terhadap ekspektasi-ekspektasi warga terhadap tempat bekerja dan rumah yang kemudian berubah dan meningkat dari kapasitas fungsi ruang-ruang tersebut, hal ini terjadi karena masyarakat butuh untuk memenuhi kebutuhan sosial mereka. Hubungan domestik dan pekerjaan ditekan untuk memenuhi semua yang diinginkan dan banyak yang tidak tercapai dalam gaya hidup terbatas mereka yang tidak memiliki komunitas (Ray Oldenburg, 1999). Hal ini sering terjadi di lingkungan kota Jakarta, salah satunya yaitu di kelurahan Pisangan Timur, Kecamatan Pulo Gadung. Kelurahan Pisangan Timur merupakan Kawasan yang di dominasi oleh perumahan, peruntukan lahan yang dipergunakan untuk pemukiman/perumahan yaitu sebesar $89.63 \%$ dan sisanya di pergunakan untuk jalan, jalur hijau/taman, dan danau. Dengan minimnya jumlah lahan yang kemudian di peruntukan untuk taman, kemudian berdampak pada aktifitas warganya yang kemudian menjadi menyimpang, antara lain, warga kemudian mulai mencari tempat untuk beraktifitas Bersama di tempat yang tidak semestinya seperti melakukan senam pagi di depan pertokoan ketika belum buka dan juga anak-anak yang kemudian bermain bola di gang-gang yang kemudian juga dapat menbahayakan.

Adapun beberapa masalah lainnya seperti penggusuran-penggusuran pasar loak untuk jalur rel kereta api, hal ini juga kemudian mempersempit ruang-ruang publik yang dikarenakan pertokoan- pertokoan ini juga mengundang para warga untuk datang dan bertukar informasi alih-alih para warga yang sekarang lebih senang keluar rumah dan berkomunikasi dengan tetangganya di gang- gang rumahnya. Maka itu di butuhkan Project Pisanga Nuansa Retro yang merupakan bangunan dengan fungsi utama komersial berupa pasar loak yang dapat mewadahi kebutuhan interaksi sosial warga kelurahan Pisangan Timur. Bangunan ini nantinya akan di rancang bernuansa retro, retro sendiri merupakan definisi untuk menunjukkan budaya yang sudah lama ada. Bisa juga menggambarkan tren yang dikenal dari masa lalu. Kata ini berasal dari bahasa latin yang merupakan sebuah awalan. Retro artinya "mundur" atau bisa juga diartikan pada "masa lalu". Hal ini kemudian dipilih dikarenakan adanya ketertarikan warga terhadap barang-barang lawas dan sesuai dengan fungsi utama pada bangunan yaitu pasar loak, hal ini kemudian akan dikombinasikan dengan karakter warganya sehingga menghasilkan ruang publik yang dapat di akses oleh seluruh warga kelurahan Pisangan Timur.

\section{Tujuan}

Dilansir dari McLaren (2015), menyatakan bahawa sifat alami dari kota adalah memungkinkan dan mengharuskan manusia di dalamnya untuk saling berbagi sumber daya barang, jasa. Pengalaman. Kota kemudian disebut sebagai area kolaborasi, yang mana hanya dapat di bentuk jika para specialis dari berbagai bidang bekerjasama. Sehingga infrastruktur kota saat ini seperti ruang pelayanan publik, area social dan area untuk melestarikan budaya adalah sebuah tempat yang di haruskan. Kota modern juga kemudian akan membentuk masyarakat yang menjadi semakin bergantung satu sama lainnya jauh lebih besar dari sebelumnya. Dengan demikian untuk menciptakan Third place yang kemudian dapat dinikmati untuk semua lapisan masyarakat, program ruang juga harus melihat dari apa yang dibutuhkan masyarakat di sekitar Kawasan tapak yang akan di bangun. Proyek ini kemudian memiliki beberapa fungsi yang kemudian semua fungsi ini diambil dari kebiasaan-kebiasaan masyarakat yang tinggal pada kelurahan Pisangan Timur dan diantara Kawasan tapak.

Sehingga diproyek ini yaitu Pisangan Nuansa Retro diharapkan dapat menciptakan Third place yang mana adalah sebuah ruang publik yang lebih teratur sehingga tidak ada orang yang merasa dirugikan dengan adanya ruang publik ini, proyek ini juga di harapkan dapat menciptakan ruang publik yang netral agar para penggunanya dapat merasakan kenyamannan dan keterbukaan sehingga semua lapisan masyarakat dapat datang dan saling berkomunikasi satu sama lain, dan 
memungkin adanya pertukaran informasi, pengalaman suberdaya barang dan jasa. Proyek ini juga kemudian mengacu pada Sustainable Development Goals yang merupakan agenda pembangunan berkelanjutan yang di buat untuk mengatasi adanya kemiskinan, kesenjangan, dan perubahan iklim dalam bentuk aksinyata. Antara lain:

a. Tujuan 1 - Tanpa kemiskinan

Proyek ini kemudian menampung dan juga memfasilitasi para pedagang barang-barang loak yang di gusur oleh PT.KAl untuk membuat jalur rel kereta baru, hal ini kemudian bentuk upaya pengurangan kemiskinan.

b. Tujuan 5 - Kesetaraan gender

Proyek ini kemudian hadir dengan tidak melihat adanya perbedaan gender karena semua dapat hadir di tempat ini.

c. Tujuan 8 - perkerjaan layak dan pertumbuhan ekonomi

proyek ini juga menyediakan lapangan pekerjaan untuk semua orang yang ingin berjualan di tempat ini, yang kemudian akan menumbuhkan ekonomi masyarakat sekitar

d. Tujuan 9 - infrastruktur, industri, dan inovasi

Dengan adanya proyek ini, proyek ini akan mengundang para masyarakat untuk datang dan persosialisasi dan berbincang yang kemudian dapat menciptakan inovasi dan kolaborasi.

e. Tujuan 10 - berkurangnya kesenjangan

Proyek ini tidak mengenal adanya kesenjangan sosial karena status sosial ekonomi tidak penting sehingga memungkin adanya rasa kesamaan di atara penggunanya.

f. Tujuan 16 - perdamaian, keadilan dan kelembagaan yang Tangguh

proyek ini kemudian mendorong masyarakat duduk dan berinteraksi dengan damai.

\section{KAJIAN LITERATUR}

\section{Open Architecture}

Open city merupakan istilah utopian yang bertujuan pada usaha arsitek dan perancang kota untuk menerjemahkan "Open Society" (masyarakat dengan pemerintah yang toleran toleran dan inklusif, di mana berbagai kelompok mengembangkan mekanisme yang fleksibel untuk menyelesaikan segala perbedaan). Open city juga kemudian mengacu pada tempat-tempat dimana berbagai individu dari berbagai latar belakang dapat hidup berdampingan, dimana interaksi mengarah pada kekayaan dan inovasi budaya, dan di mana pasar berkembang.

Akan tetapi Open city bukan merupakan tempat yang spesifik, dimana kodisi ini hanya di temukan di sebgaian kecil dari sebuah kota dan memiliki keseimbnagan yang rapuh antara kekuatan integrasi dan disintegrasi. Namun jika Open city bukanlah merupakan tempak yang spesifik, maka Open architecture merupakan tempat yang lebih spesifik danharus mendapatkan perhatian khusus pada masyarakan untuk membentuk ini sebagai bagian dari kehidupan masyarakat.

Open architecture, merupakan the third place bagi masyarakat kota, yang berfungsi sebagi ruang antara, ruang yang bukan merupakan rumah tinggal (home) dan bukan tempat kerja. the third place adalah sebuah program yang akan membantu masrakat kota agar bersifat humanis, terbuka, dinamis dan produktif. (realrich sjarief, 2019).

\section{Third Place}

Dalam kehidupan sehari-hari the third place merupakan tempat yang penting, selain first place yang merupakan home dan juga second place yaitu tempat bekerja, third place kemudian hadir sebagai tempat publik yang netral, yang dapat di gunakan siapa saja dan kapan saja. Third place kemudian juga muncul dengan bentuk yang beragam karena menyesuaikan dengan kehidupan warga. Ray Oldenburg, dalam bukunya Oldenburg's (1999) eight characteristics of "third places" menyatakan definisi Third place adalah sebuah "jangkar" bagi para komunitas dengan fasilitas yang mendorong interaksi luas dan kreatif. Dengan kata lain Third place adalah "sebuah tempat yang memberikan kenyamanan untuk bersantai di depan umum, dan sebuah tempat untuk bertemu dengan wajah-wajah baru unruk berkenalan.". Dalam bukunya Oldenburg's (1999) 
eight characteristics of "third places" juga memperkenalkan delapan karakteristik tentang Third place, antara lain :

a. Neutral ground

Pengguna Third place tidak memiliki kewajiban untuk berada di tempat ini, tidak terikat secara finansial, politik, hukum, atau sebaliknya. Artinya pengguna bebas untuk datang dan pergi dari tempat ini.

b. Leveler (a leveling place)

Pengguna Third place tidak memetingkan status individu, dalam tempat ini status sosial ekonomi tidak penting sehingga memungkin adanya rasa kesamaan di atara penggunanya.

c. Conversation is the main activity

Adanya percakapan yang menyenangkan adalah arti utama Third place

d. Accessibility and accommodation

Third place harus terbuka dan mudah di akses bagi para penggunanya, dan juga akomodatif, artinya Third place harus memenuhi kebutuhan penggunanya

e. The regulars

Third place harus memiliki sejumlah pengunjung tetap yang membantu mengatur suasana hati dan karakteristik daerah. Para pengunjung tetap juga dapat menarik pendatang baru sehingga merasa di terima.

f. A low profile

Third place merupakan tempat yang tidak ditujukan untuk pemborosan, melainkan Third place memberikan kesan yang sederhana, sehingga dapat menerima semua lapisan masyarakat.

g. The mood is playful

Third place merupakan tempat yang tidak pernah di tandai dengan ketegangan atau permusuhan, melaikan Third place merupakan tempat menyediakan ruang untuk percakapan cerdas dan tempat bercanda yang ringan.

h. A home away from home

Para pengguna Third place merasakan tempat ini seperti rumah bagi penggunanya dikarenakan adanya perasaan hangat dan kepemilikan, sehingga para penggunanya dapat menghabiskan waktu di tempat ini.

Mikunda, C, dalam bukunya yaitu Brand Lands, hot spot \& cool space, memperkenalkan gagasan tentang Third place yang merupakan tempat sementara yang memenuhi kebutuhan emosional. Sementara memahami tentang Third place yang di kemukakan Ray Oldenburg, Mikunda berpendapat bahwa konsep Third place yang di kemukakan Ray Oldenburg telah punah dengan kebutuhan masyarakat sekarang yang membutuhkan tempat untuk menghabiskan waktu luangnya. Museum, toko dengan konsep, dan pameran berfungsi sebagai tempat ketiga baru karena mereka adalah tempat di mana orang merasa sementara di rumah dan di mana mereka dapat meluapkan emosi mereka. Oleh karena itu Third place yang baru merupakan daya tarik wisata di mana fokusnya bergeser dari situs di mana orang menjadi pusat perhatian kemudian menjadi tempat di mana orang menjadi penonton. Mikunda kemudian menggambarkan empat karakteristik dari Third place ini, antara lain:

a. Tempat yang menarik perhatian pengguna dan di desain dengan spektakuler.

b. Tempat yang di rancang untuk membawa pengguna berjalan-jalan sampai mereka menemukan barang yang ingin mereka beli.

c. Tempat memiliki tema dan konsep

d. Memiliki dayatarik yang membuat pengguna ingin datang.

Richard Florida, dalam bukunya yaitu The Rise Of The Creative Class, Revisited mendeskripsikan tentang kemunculan kelas sosial yang tumbuh yaitu creative calss. Kreatifitas merupakan sumberdaya yang mendiring kelas soal yang selaran dengan perkembangan pertumbuhan ekonomi. Dengan mengerti bagaimana kemunculan kelas social ini beserta Value-nya. Banyak 
ahli ekonomi yang beranggapan bahwa pertumbuhan ekonomi disebabakan oleh perusahanperusahaan dikarenakan semakin besar perusahaan, investasi, peralatan, dan lain-lain yang dimiliki, semakin besar pertumbuhan ekonomi yang terjadi. Akan tetapi adapun terdapat teori ekonomi baru yang menyatakan bahwa bukan hanya perusahaaan yang kemudian menyebabkan pertumbuhan ekonomi, tetapi terdapat juga factor lain yaitu teknologi yang juga berkembang penting dalam meningkatkan pertumbuhan ekonomi.Namun teknologi tidak dapat berkembang dan berjalan dengan sendirinya, teknologi membutuhkan kreatifitas manusia. Manusia yang memiliki kemampuan untuk menggunakan teknologi secara maksimal, sehingga akan menghasilkan sebuah karya yang dapat memberikan pertumbuhan ekonomi yang diharapkan. Hal-hal yang kita gunakan seperti baju, tas handphone, computer, dan lain-lain merupakan hasil dari kreativitas manusia.

Kunci untuk meningkatkan ekonomi adalah dengan mengumpulkan orang-orang yang kreatif, bukan hanyadi negeri sendiri melainkan seluruh negeri. Pada era ini, semua orang adalah orang kreatif, dimana semua orang membutuhkan rekreasi di luar yang dapat mempertemukan mereka dengan orang-orang kreatif lainnya. Ada kasus pada saat ini yang menunjukan dimana orangorang biasanya menonton televisi dan minum bir ketika pulang kerja ataupun mereka yang biasanya pergi ke tempat gym untuk melatih tubuh mereka atau hal-hal kreatif lainnya yang dapat dilakukan untuk menstimulasi kreatifitas. Dalam dunia kerja yang keras, ada saat-saat dimana orang-orang ini membutuhkan tempat untuk beristirahat sejenak. Orang-orang kemudian ingin mendengarkan atau menonton pertunjukan musik, seni, galeri, dan makan di restoran dimana mereka bisa saling berkumpul dan bersosialisasi menghilangkan stress dan mengembangkan stimulasi kreatif.

Orang-orang kemudian membutuhkan tempat terbuka(open) dimana tempat yang tidak memperdulikan etis, gender, umur, agama, pekerjaan, dan orientasi seksual. Tempat yang dapat di jadikan sebagai tempat pelarian dari stress sekaligus tempat untuk membentuk komunitaskomunitas yang dapat mebantu individu. Maka dari itu, sangat penting menghadirkan sebuah wadah atau tempat dimana tempat tersebut dapat menampung orang-orang kreatif dan dapat mengembangkan setiap kreatitifitas tiap individu yang kemudian dapat mengembangkan kualitas hidup mereka. Charlotte Buehler, merupakan seorang sosiologi terkemuka eropa, ia menyatakan bahwa "sosialisasi ialah proses yang membantu individu melalui belajar dan menyesuaikan diri, bagaimana cara hidup dan bagaimana carai berpikir kelompoknya, agar dapat berperan dan berfungsi dalam kelompoknya". Melalui proses sosial inilah yang kemudian akan membentuk masyarakat menjadi kelompok-kelompok sosial, dari kelompok sosial tersebutlah kemudian akan membentuk masyarakat sosial dalam arti yang lebih luas lagi. Ciri dari masyarakat sendiri ialah adanya sejumlah manusia yang tinggal dalam suatu daerah tertentu yang memiliki hubungan yang tetap dan teratur satu sama lain, masrakat sendiri terikat karena memiliki berbagai kepentingan bersama serta sadar akan interpendensi satu sama lain, berdasarkan system yang terbentuk, dengan sendirinya membentuk norma-norma yang akhirnya membentuk kepudayaan Bersama.

\section{METODE}

\section{Metode Perancangan}

Dalam strategi perancangan adapun penggunaan teori, dalam hal ini teori metode perancangan yang digunakan adalah milik Kengo Kuma, Kengo Kuma murupakan arsitek yang yang memiliki aliran kontemporer. Kengo Kuma menghidupkan dan merevilitasi nilai dan nilai adat istiadat tradisional jepang, yaitu dengan menghargai alam di era masa kini. Kengo Kuma meiliki desain yang berfocus pada material dan konektifitas emosional tradisi Jepang. Kengo Kuma selalu menggabungkan lingkungan binaan dengan sumber daya alama seperti cahaya alami. Kengo Kuma dalam mendesain sangat memperhatikan lokasi proyek, lingkungan morfologi, topografi, sejarah dan budaya setempat serta masyarakat. Hal ini di lakukan, agar dapat berkomunikasi 
dengan masyarakat sekitar, mersakan udara, dan menginjak tanah pada tapak. Desain Kengo Kuma dimulai dengan adanya komunikasi, Kenko kuma memiliki sifat dematerialisasi antara arsitektur dan lansekap, memungkinkan cahaya dan suara masuk pada arsitektur dimana bertolak belakang dengan sifat material itu sendiri (Vignjevic, 2015).

Menurut Michael (2011), Kongo kuma memiliki karakteristik pada desainnya, antara lain:

a. Transcendence;

Mendesain bangunan dengan membuka peluang untuk menghungkan subjek dengan dunia luar. Hal ini dimaksutkan untuk menghadirkan konektivitas antara lingkungan luar dengan pengguna yang kemudian mengkaburkan batas-batas objek.

b. Passivity;

Mencegah keberadaan arsektur menjadi suatu objek. Kuma membangun bangunan yang memiliki sifat pasif yang kemudian akan bertindak sebagai septor.

c. Particilization;

Arsitektur memiliki hal yang penting antara lain rencana, bentuk, dan elevasi, namun Kuma mengilutrasikan arsitektur menjadi particilization seperti pelangi. Kuma kemudian menyatakan bawa pelangi bukanlah hal yang mutlak dikarenakan pelangi di hasilkan dari hungan antara matahari, tetesan air dan pengamat. Sama dengan arsitektur Kuma kemudian memandang arsitektur merupakan hasil dari hubungan antra alam, bangunan, dan manusia.

d. Temporality; Temporality adalah perbedaan antara waktu dan ruang.

e. Subject-Object Relationship;

Menciptakan arsitektur bukan sebagi objek, dengan cara menciptakan hubungan dengan objek dan subjek. Pada pandangan Kuma individu tidak akan mengakui eksistensi bangunan keculai individu tersebut menjasi bagian dari bangunan.

\section{Pendekatan Perancangan}

Dalam pendekatan perancangan untuk proyek ini adalah metode lan Benley dalam bukunya Responsive Environment, 1985 . Metode Responsive Environment merupakan upaya untuk menciptakan lingkungan yang responsif, terdapat 7 aspek yang perlu dipenuhi, antara lain:

\section{Permeability}

Permeabilitas merupakan akses dan sirkulasi yang kemudian menjadi penting untuk menciptakan kawasan yang responsive. Dalam mendisain tapak perancang kemudian harus memutuskan berapa banyak sirkulasi yang harus ada, dan bagaimana sirkulasi kemudian memberikan akses untuk mencapai fungsi-fungsi lain di luar kawasan. Metode yang dapat dilakukan untuk menciptakan permabilitas:

a. Menggunakan penghubung yang sudah ada;

b. Merancang jalan / blok;

c. Membagi jenis jalan dan merancang persimpangan; dan

d. Memeriksa ukuran dari blok.

\section{Variety}

Tempat yang mudah di akses tidak akan berhasil jika tempat tersebut tidak meiliki banyak fungsi oleh karena itu kunci kedua dalam menciptkan kawasan yang responsive adalah variety.

Pada tahap ini dalam memaksimalkan fungsi dari kawasan, perancang perlu mengetahui permintaan utuk berbagai jenis fungsi baru di kawasan dan menetapkan berapa luas fungsi yang di perlukan secara ekonomis.

\section{Legibility}


Selanjutnya setelah fungsi-fungsi yang diwarkan pada suatu kawasan sudah ditetukan, pada tahap ini perancang akan merancang tata letak fungsi tersebut. jaringan penghubung dan fungsi yang ada kemudian diolah sebagai elemen yang mampu memberi persepsi yang membawa orang-orang pada fungsi atau identitas tertentu. Termasuk menciptkan jalur-jalur yang dapat memberikan batas ruang spasial yang berbeda.

\section{Robustness}

Pembuatan ruang luar yang harus ada pada bangunan dikarenakan tempat tersebut memungkinkan untuk berbagai aktivitas atau kegitan-kegiatan yang memungkinkan ada pada masa depan.

\section{Visual Appropriateness}

Pemberian identitas pada bangunan merupakan hal yang penting dikarenakan desain pada bangunan akan sangat mempengaruhi pengguna dalam penyampayan pesan diterima atau tidak di terima.

\section{Richness}

Pada hal ini perancang akan berhadapan dengan rincian projek. Perancang harus dapat menciptakan kekayaan rasa baik secara visual maupun non-visual, dalam hal ini perancang harus memilih bahan dan Teknik konstruksi yang cocok untuk mencapainya.

\section{Personalisation}

Merupakan tahap dimana para pengguna memrikan cap pada lingkungan mereka sendiri sebagai hasil dari respon pengguna terhadap lingkungan itu sendiri.

\section{DISKUSI DAN HASIL}

Pisangan Nuansa Retro berlokasi di Jl. Pisangan Lama 2, Kec.Pulo Gadung, Kel. Pisangan Timur, Jakarta timur. Fungsi dalam Proyek ini yaitu area makanan, pasar loak, workshop, popup marked, dan ruang komunal. Keseluruhan bangunan dengan luas $4.900 \mathrm{~m}^{2}$ terbangun di atas tanah seluas $2.452 \mathrm{~m}^{2}$.

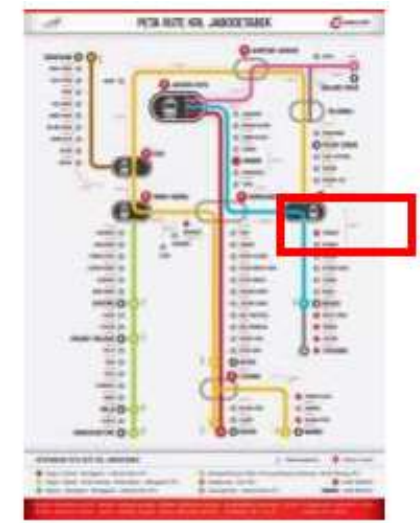

Gambar 1 Peta Rute KRL Jabodetabek Sumber: transportasiumum.com, 2020

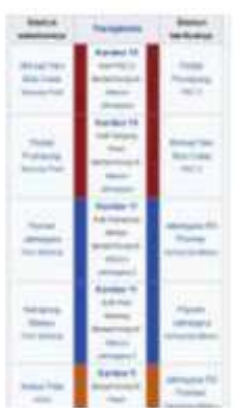

Gambar 2. Stasiun Transjakarta Sumber: id.wikipedia.org, 2020

Transit oriented development, adalah penggabungan antara kawasan transit dengan suatu lahan campuran, dimana di kawasan tersebut harus meliputi fungsi yang lengkap, dapat dijangkau dengan berjalan kaki, serta dengan kawsan transit. (Transit-Oriented Development Guidebook, 2006). Definisi dari TOD kemudian juga di artikan sebagai kawsan campuran yang dapat di akses dengan tidak lebih dari 2000 kaki atau setara dengan $609.6 \mathrm{~m}$ dari terminal transit dan memiliki area komersial. Kwasan TOD juga harus memiliki fungsi seperti hunia, pertokoan, kartor, ruang terbuka serta ruang terbuka yang dapat di gapai dengan berjalan kaki. (Peter Calthorpe, The Next American Metropolis, 1993). Stasiun jatinegara merupakan stasiun 
yang berjarak $500 \mathrm{~m}$ dari lokasi tapak stasiun jatinegara sendiri merupakan stasiun kelas bertipe A yang terletak di perbatasan antara Jatinegara dan juga matraman,sebagai stasiun yang menghubungkan semua KA berbagai kota di Pulau Jawa (kecuali arah Banten dan Bogor), kelurahan Pisangan Timur juga memiliki berbagai transportasi lain antara lain, TransJakarta dan juga mikrolet. Berdasarkan kriteria tersebut pemilihan kawasan tapak, yang dituju dimana menyediakannya wadah ruang ketiga untuk masyarakat. Memilih kawasan kota dengan kebutuhan RTH yang tinggi dan banyaknya trasportasi umum yang melewati, kemudian dipilihlah tapak yang berada pada kecamatan Pulogadung, Kelurahan Pisangan Timur.

\section{Kondisi Eksisting kawasan}

Kelurahan Pisangan Timur merupakan kelurahan yang sebagian besar dari jumlah kawasannya terdiri dari perumahan atau bangunan yaitu sebesar $89.63 \%$ dan sisanya dipergunakan untuk jalan, danau dan taman, peruntukan penggunaan lahan pada wilayah Kelurahan Pisangan Timur dapat dilihat dengan jelas dari table berikut ini:

Tabel 1. Peruntukan dan Luas Tanah

\begin{tabular}{|c|c|c|}
\hline Peruntukan Tanah & Luas Tanah & Persentase (\%) \\
\hline Perumahan / bangunan & 160.28 & 89.63 \\
\hline Jalan & $16.982 \mathrm{~m} 2$ & 9.47 \\
\hline Jalur hijau / Taman & 1.5 & 0.83 \\
\hline Danau & 0.1 & 0.05 \\
\hline jumlah & 179.21 & 100 \\
\hline
\end{tabular}

Sumber: data kelurahan Pisangan Timur kecamatan Pulo Gadung Jakarta Timur

Kelurahan Pisangan Timur merupakan kawasan yang yang memiliki banyak pusat-pusat perekonomian masyarakat seperti pasar moderen, pasar tradisional dan juga berbagai toko.

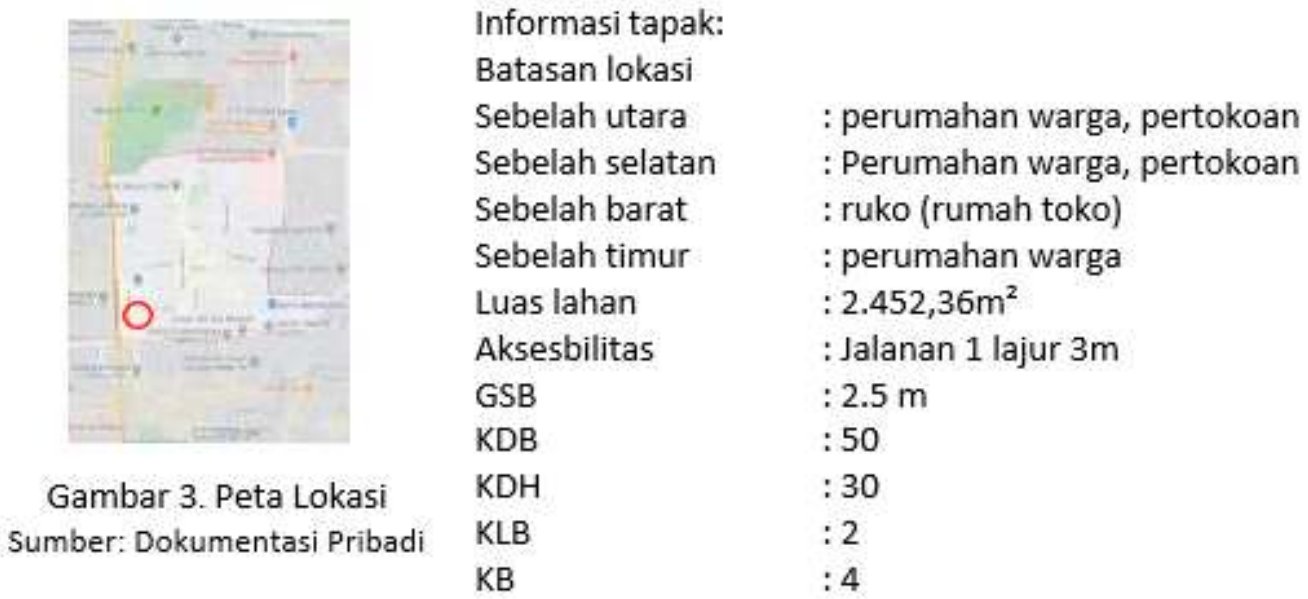


Penggusuran Pasar Loak

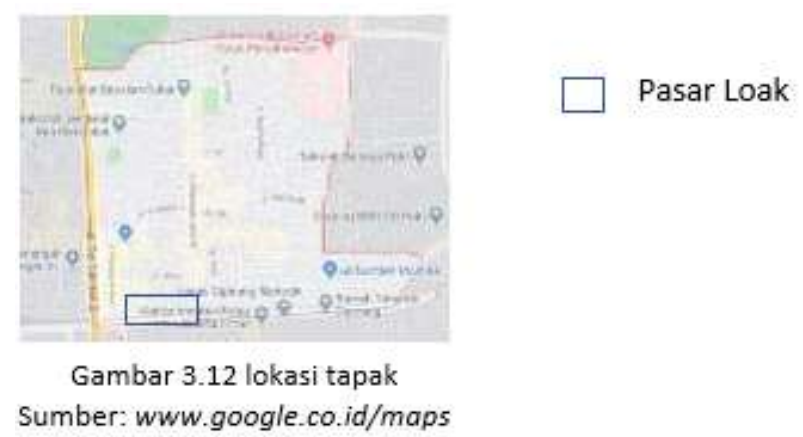

Pada kelurahan Pisangan Timur ada sejumlah titik pedagang yang menjual barang-barang loak, namun para pedagang ini menjual barang-barang dagangannya di sepanjang trotoar dan menaruh beberapa barangnya di pinggir-pinggir jalan yang kemudian mengganggu para pejalan kaki dan kendaraan bermotor. Pada akhir tahun 2019, PT. Kereta Api Indonesia kemudian membongkar sebagian dari tempat berjualan para pedagang barang-barang loak yang berada di kelurahan Pisangan Timur untuk kebutuhan infrastruktur yaitu menambah 1 buah jalur rel kereta. Hal ini cukup di sayangkan karena mengingat banyaknya warga yang kemudian dapat berkumpul baik anak-anak, remaja, maupun orang tua di tempat ini. Dari hasil analisa terhadap kawasan Kel. Pisangan Timur maka diperoleh sebuah kesimpulan bahwa tapak terpilih sangat cocok untuk program third place yang akan diajukan dan tapak ini juga terletak diantara perumahan dan tempat kerja, sehingga sering kali di lewati dan dapat menjadi tempat persinggahan. Selain itu juga tapak ini sangat strategis dan dekat akan pemberhentian transportasi umum sehingga mempermudah pencapaian.

\section{Analisis Konsep dan Program Kegiatan}

Rincian Usulan Program

\section{a. Commercial}

Pada kelurahan Pisangan Timur ada sejumlah titik pedagang yang menjual barang- barang loak, namun para pedagang ini menjual barang-barang dagangannya di sepanjang trotoar dan menaruh beberapa barangnya di pinggir-pinggir jalan yang kemudian mengganggu para pejalan kaki dan kendaraan bermotor. Pada akhir tahun 2019, PT. Kereta Api Indonesia kemudian membongkar sebagian dari tempat berjualan para pedagang barang-barang loak yang berada di kelurahan Pisangan Timur untuk kebutuhan infrastruktur yaitu menambah 1 buah jalur rel kereta. Hal ini cukup di sayangkan karena mengingat banyaknya warga yang kemudian dapat berkumpul baik anak-anak, remaja, maupun orang tua di tempat ini. Pasar loak adalah respon yang dibentuk untuk menampung para pedagang loak yang kemudian mengganggu para pejalan kaki dan kendaraan bermotor serta menciptakan tempat yang lebih terintegrasi sehingga warga dapat datang dan berkumpul dengan lebih nyaman.

b. Education

Tempat ini yang merupakan tempat yang dapat digunakan untuk para warga menyelenggarakannya berbagai workshop dan berbagai kegiatan kesenian. Program ini kemudian muncul juga sebagai wadah yang dapat merealisasikan salah satu hasil dari Mursrenbang yaitu peningkatan kualitas warga dengan diadakannya berbagi pelatihan seperti keterampilan menjahit, merias, pelatihan satpam, dan lainnya.

c. Food Matked

Tempat ini berfungsi sebagai area untuk para warga dan para pengguna lainnya, berkumpul dan makan bersama. Program ini terdiri dari beberapa pendagang yang menjual FnB. Program ini dapat terlahir dikarenakan adanya respon terhadap para pedangan yang berjulan di atas trotoar yang kemudian menggangu para pengguna jalan raya dan juga pada pejalan kaki, serta menciptakan tempat yang lebih terintegrasi sehingga warga dapat 
datang dan berkumpul dengan lebih nyaman.

\section{d. Edutainment}

Tempat ini merupakan area yang di buka 24 jam, area ini berfungsi sebagai area untuk para warga dan pengguna lainnya berkumpul duduk dan berkomunikasi satu sama lain dengan ditemani berbagai hasil workshop yang diperjual belikan di area pop up market.

\section{Bentuk Rancangan}

Bentuk dasar bangunan berasal dari bentuk aksis tapak, yang kemudian pada area lantai dasar diberikan konsep permeabilitas yang menghubungkan pejalan kaki pada area perumahan warga dan area komersil di kelurahan Pisangan Timur, selanjutnya massa yang terbentuk kemudian diberikan akses berupa tangga yang dapat diakses langsung dari area luar massa untuk masuk ke area massa pada lantai dasar dan lantai 2, kemudian massa di berikan void yang menembus dari lantai teratas massa hingga lantai dasar pada massa, void ini berfungsi untuk memberikan sirkulasi udara silang secara tegak vertikal.

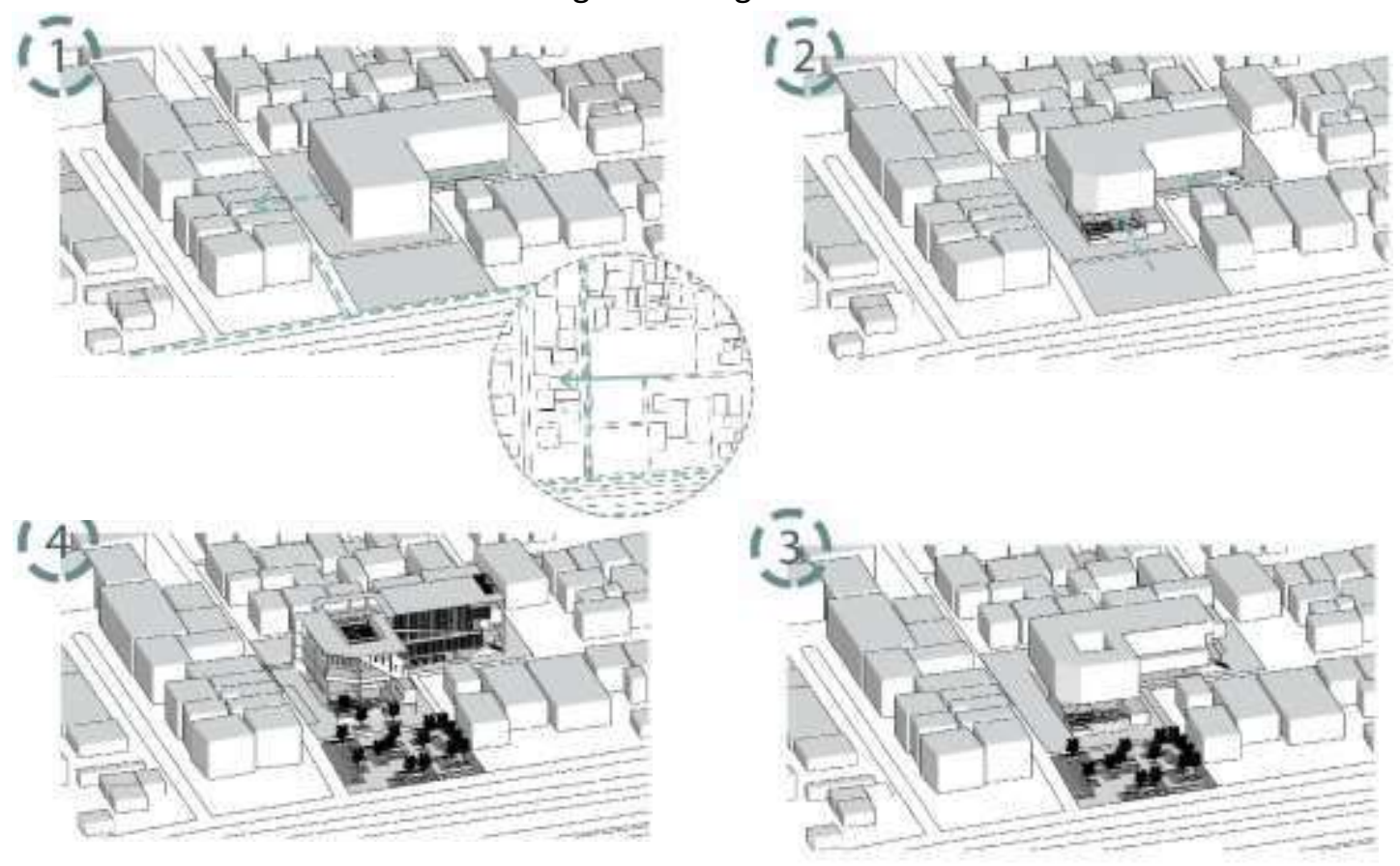

Gambar 4. Design scheme

Sumber: Dokumentasi Pribadi,2020

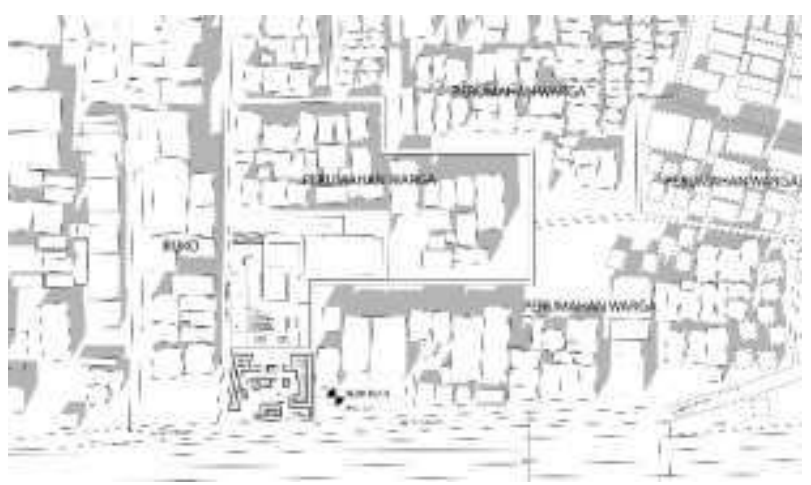

Gambar 5. Blok plan

Sumber: Dokumentasi pribadi, 2020

Bangunan ini Terdiri dari 5 Lantai bangunan, lantai yang pertama difokuskan untuk area Popup 
Maket dan komunal. Lantai yang kedua untuk area pasar loak, area pengelola, dan cafe. Lantai yang ketiga untukfood market, pasar loak, dan musholla. Lantai keempat untuk area workshop, dan area pada lantai B1 merupakan area parkiran mobil dan motor.

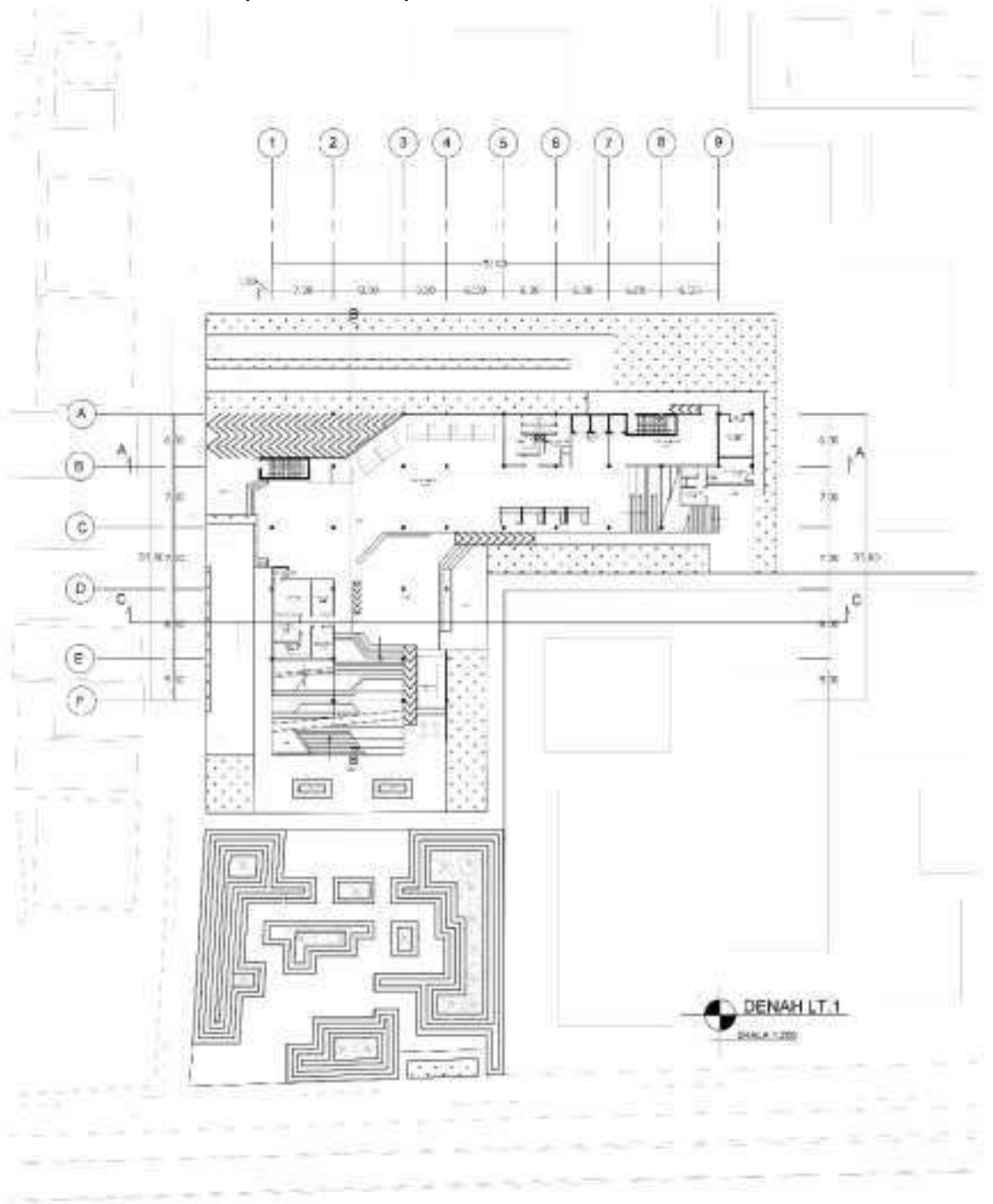

Gambar 6. Denah Lantai 1

Sumber: Dokumentasi Pribadi, 2020

Pada denah lantai dasar memperlihatkan bagaimana sirkulasi pejalan kaki (people movement) yang masuk ke dalam tapak dan juga sebaliknya. Dengan pemisahan akses kendaraan dan pejalan kaki, membuat tapak menjadi lebih menghargai pejalan kaki dan tidak ada crossing di dalam tapak. Pada denah lantai dasar juga menghubungkan area perumahan dan area komersial dengan menggunakan konep permeabilitas. 


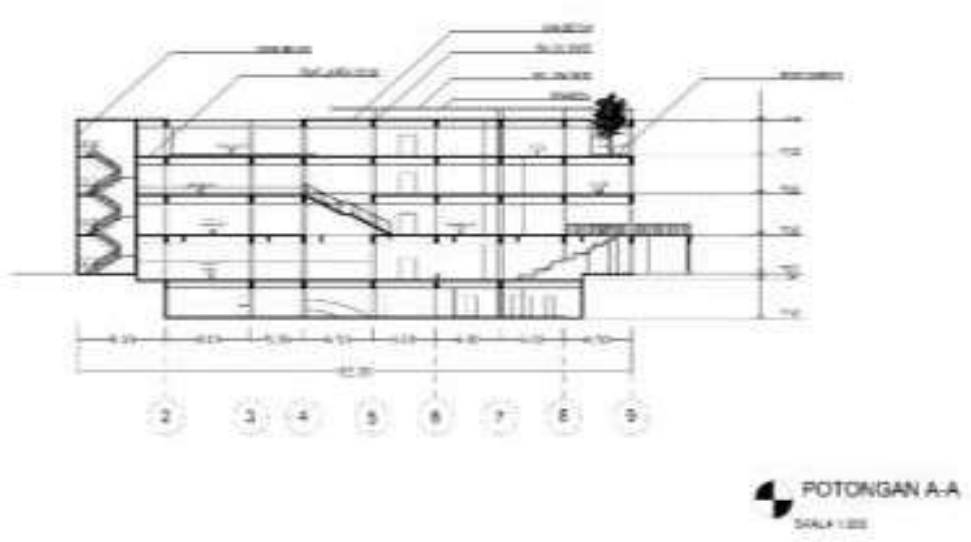

Gambar 7. Potongan A-A

Sumber: Dokumentasi Pribadi, 2020

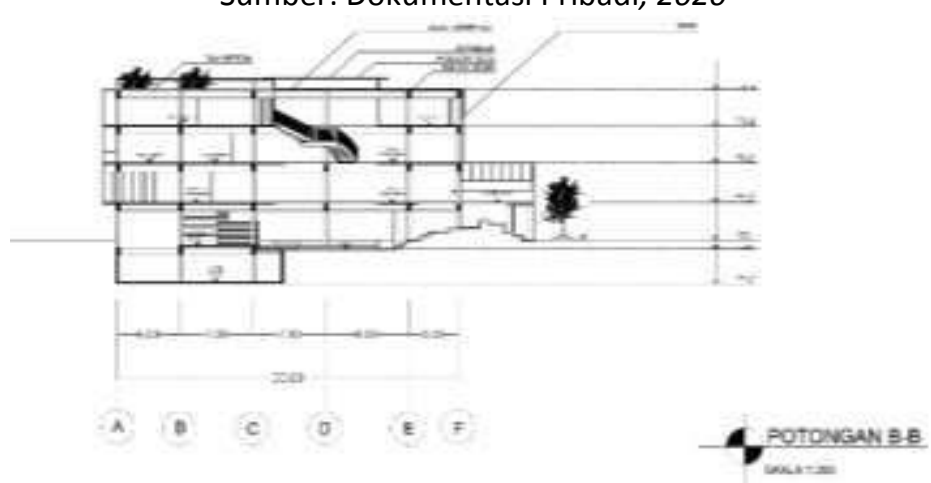

Gambar 8. Denah Potongan B-B

Sumber: Dokumentasi Pribadi, 2020

Dari gambar potongan dapat dilihat bagaimana sistem struktur bangunan yang digunakan pada bangunan ini, selain itu juga memperlihatkan bagaimana hubungan antar ruang secara vertikal.

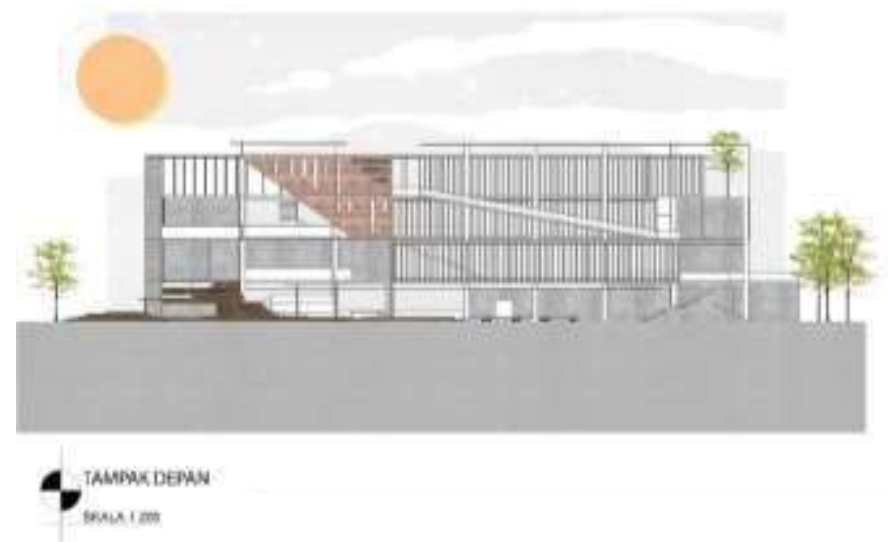

Gambar 9. Tampak Depan

Sumber: Dokumentasi Pribadi, 2020 


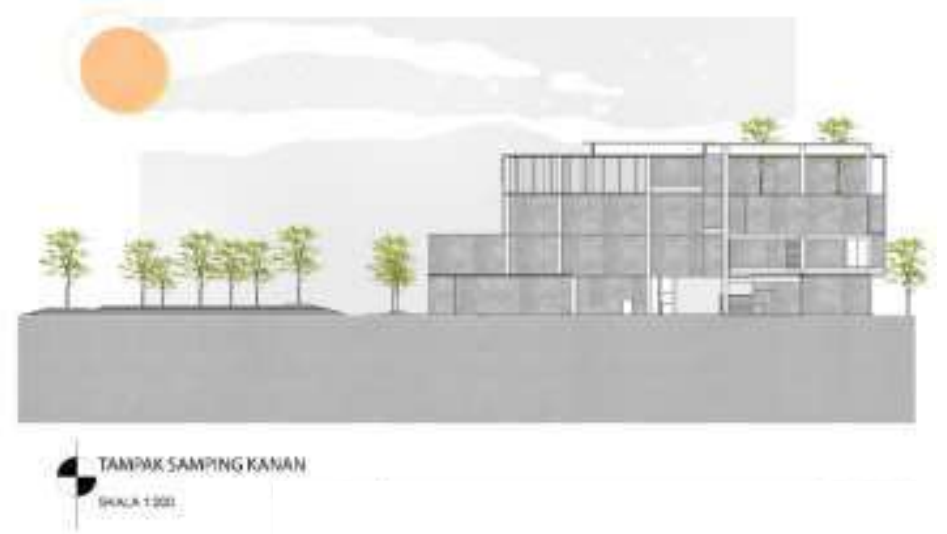

Gambar 10. Tampak Samping Kanan

Sumber: Dokumentasi Pribadi, 2020

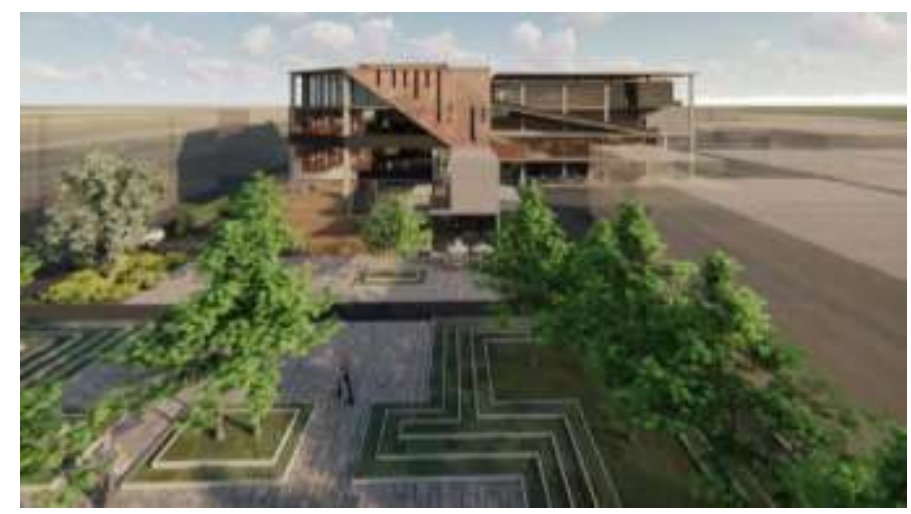

Gambar 11. Eksterior Bangunan

Sumber: Dokumentasi Pribadi, 2020

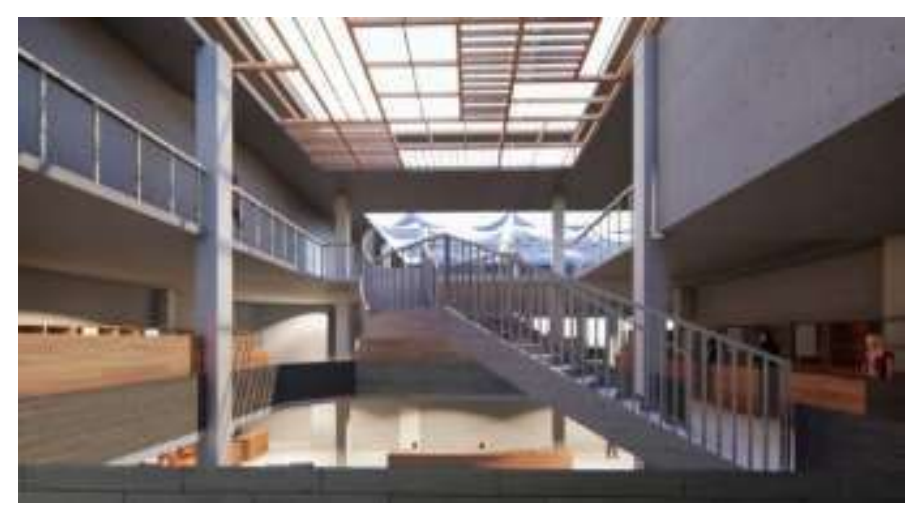

Gambar 12. Interior Bangunan

Sumber: Dokumentasi Pribadi, 2020 


\section{KESIMPULAN}

\section{Kesimpulan}

Proyek akan menghadirkan sebuah third place dengan nuansa retro yang mampu mewadahi kebutuhan masyarakat khususnya di daerah Pisangan Timur dengan mengangkat sebuah fenomena yaitu minimnya area berkumpul yang diakibatkan padatnya kelurahan pisangan timur. Program yang dihasilkan adalah membuat third place di kawasan Pisangan Timur dengan memperhatikan unsur-unsur third place dengan menerapkan berbagai teori seperti bagimana membuat Kawasan menjadi lingkungan yang responsive, membuat aktifitas yang berganti-ganti dan membuat kontekstual dengan kawasan sekitar. Dengan adanya proyek ini diharapkan masyarakat dapat bermain, berkumpul, berkomunikasi, serta belajar dalam wadah yang baik, nyaman dan aman. Serta yang diharapkan dengan terbentuknya proyek ini masyarakat dapat memanfaatkan waktu luang mereka dengan baik dengan memenuhi kebutuhan mereka akan istrahat sehingga dapat meningkatkan kinerja mereka dalam melakukan berbagai macam aktivitas.

\section{Saran}

Dalam perancangan suatu proyek third place, diperlukan pemahan yang mendalam terhadap karakteristik suatu Kawasan. Aspek-aspek venakular pada pada suatu kawasan seperti penggunaan material, iklim, dan jenis aktivitas pada Kawasan juga penting untuk mempertahankan kekhasan Kawasan.

\section{REFERENSI}

Kubis, M. (2011). Exploring The Relationship Between The Work of Kengo Kuma and The Philosophy of Jean-Paul Sartre. Retrieved February 10, 2020, Research Report.https://www.scribd.com/doc/218 694053/The-Work-of-Kengo Kuma-andthephilosophy-fo-Jean-Paul Sartre.

McLaren, D., Agyeman, J. (2015). Sharing Cities: A Case for Truly Smart and Sustainable Cities, MIT press

Mikunda, C. (2007). Brand lands, het spots \& cool spaces Welcome to the third place and the total marketing experience. London: Kogan Page

Moore, J. (2012). The art of the Third Place in a First Suburb.

Mubayyinah, M dan Utomo, C. (2012). Analisa Highest and Best Use(HBU) Lahan X Untuk Properti Komersial. Jurnal Teknik ITS, 1(1), D16-D19. Diakses 11 Februari 2020, https://docplayer.info/50391792-Jurnal-teknik-its-vol-6-no-1-2017-issn-print-d-73.html

Oldenburg, R. (1999). The great good place: Cafes, coffee shops, bookstores, bars, hair salons and other and other hangouts at the heart of a community. New York, NY: Marlowe \& Company

Oldenburg. R. (2001). Celebrating the third place: inspiring stories about the "great good places" at the heart of our communities. New York, NY: Marlowe \& Company.

Pulvers, Roger. (2013). Architect Kengo Kuma: 'A Product of Place'. The Asia Pasific Jurnal, Vol.11. Hal.3, diakses 10 Februari 2020, https://apjjf.org/2014/11/26/RogerPulvers/4141/article.html

Riccarton McGlynn, S, Smith, G, Alcock, A, Murrain, P, Bentley,I. (1985). Responsive Environments a Manual For Designers. London: Architectural Press.

https://jakartasatu.jakarta.go.id/portal/apps/webappviewer/index.html?id=ee99400 06aae4a268716c11abf64565b 